\title{
OXFORD STREET, ACCRA
}




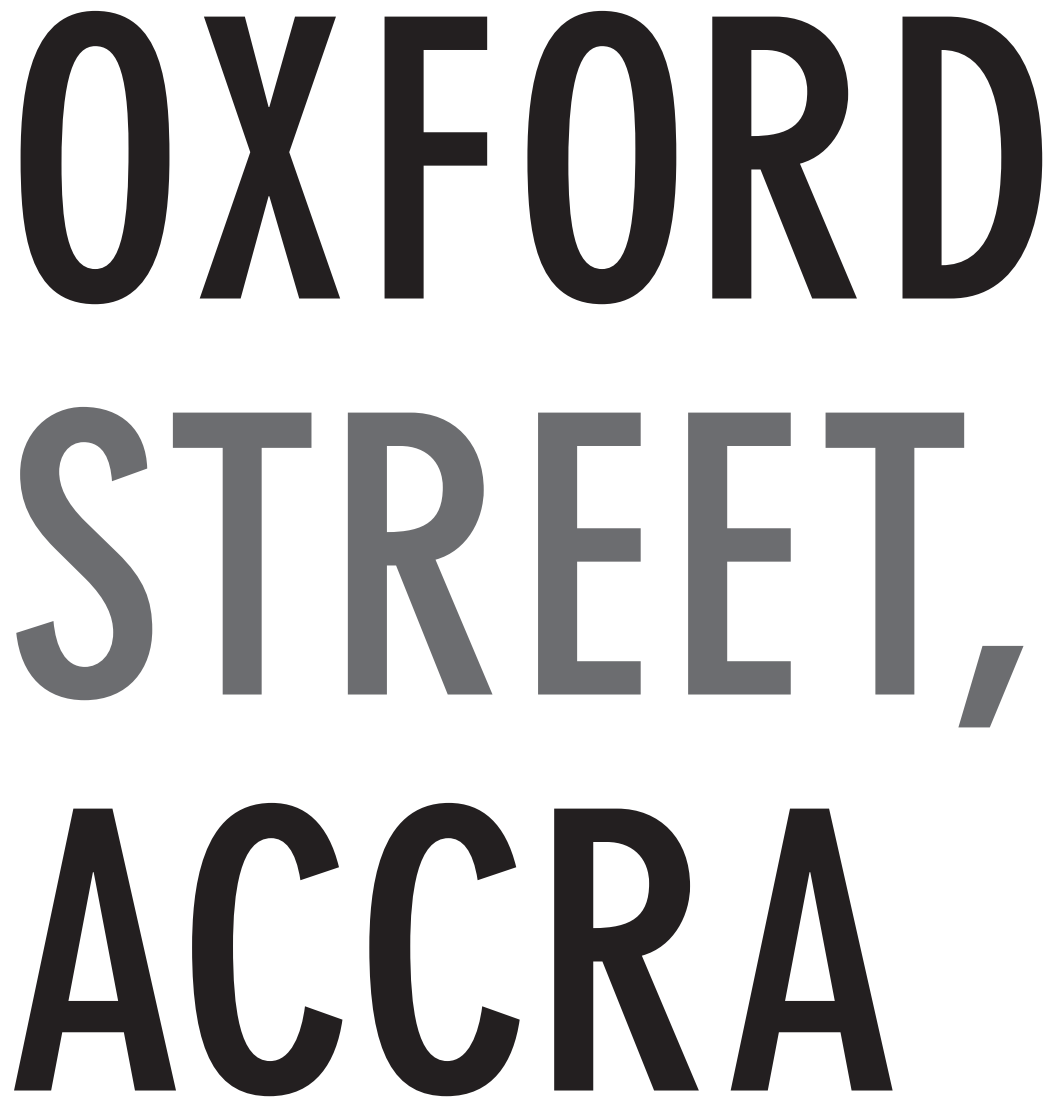

City Life and the Itineraries of Transnationalism

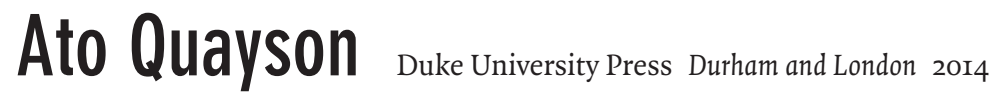


(C) 2014 Duke University Press

All rights reserved

Printed in the United States

of America on acid-free paper $\infty$

Designed by Amy Ruth Buchanan

Typeset in Quadraat by

Westchester Book Group

Library of Congress Cataloging-

in-Publication Data

Quayson, Ato.

Oxford Street, Accra : city life and the

itineraries of transnationalism / Ato Quayson.

pages $\mathrm{cm}$

Includes bibliographical references and index.

ISBN 978-0-8223-5733-9 (cloth : alk. paper)

ISBN 978-o-8223-5747-6 (pbk. : alk. paper)

I. Oxford Street (Accra, Ghana)

2. Accra (Ghana)-History. I. Title.

DT512.9.A3Q39 2014

$966.7-\mathrm{dc} 23$

2014000767

Cover art: Thomas Cockrem / Alamy 
For Rosina Ayeafer-

mother, trader, storyteller (?-2006) and Keshav, Kamau, and Kairavfor playing with my head 
